\title{
FOREIGN DIRECT INVESTMENTS UNDER IMPACT OF POLITICAL RISKS: THEORETICAL SURVEY
}

\author{
Fatih Ayhan \\ Bandırma On Yedi Eylül University, Balıkesir, Turkey
}

Beyond well-known economic indicators, political structure and social characteristics of a host country also have special importance for investors' decisions. Political risk indicators cover mainly democratization level, political/government instability, war, immigration problems, problems with neighboring countries, internal and external conflicts, corruption level, military and religious influence on politics, law and order, ethnics tensions, property rights protection, national security and geographic situation - all of these factors also deeply affect decisions on FDI. Also, some basic social characteristics for host countries can play the catalyze role for FDI, such as literacy rate, education opportunities etc. The aim of this study is to examine theoretically the relationship between political and economic risks on the one hand with FDI on the other. It is aimed to show the theoretical background for the political and economic risk factors. Statistical figures on the FDI trends worldwide will be also presented.

Keywords: foreign direct investments; political risk; economic risk; country risk; political instability; economic development; developing countries.

\section{Introduction}

Risk is a concept of daily life that affects economic and social decisions of individuals. Individuals direct their activities assessing the risk factors in the course of decision-making. Likewise, investors make their decisions on to invest or not by paying attention to the risk factors of their activities. Political risk, a type of risk that an investor is exposed to, is also one of the important factors affecting investment decisions. It is among the factors that investors primarily consider when deciding on foreign investments. Political risks that are not under their control and make it difficult to recover sunk costs are decisive for foreign direct investors.

Since the 1990s there have been significant increases in foreign direct investment volumes all over the world. Today, too quick changes in political risk elements require foreign investors to be more careful. This is especially concerns the influence of globalization, since both trade and investment can easily go beyond the borders. Both

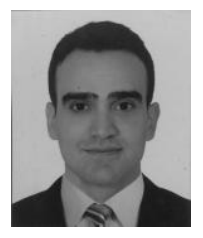

Fatih Ayhan

$\mathrm{PhD}$, ast. professor in Bandırma On Yedi Eylül University, Balıkesir, Turkey

Research interests: international market of capital, macroeconomic development, international investments, international labor market, government regulation of national trade and employment

Published more than 25 papers in international journals, few manuals for students and chapters in collective monographs in Turkish and English

Participated more than 15 international conferences

Email: fatih_ayhan@yahoo.com 
investors and host countries of FDI mutually benefit from this situation. Key advantages from cross-border investments can briefly be summarized as lower production costs, large market volume and high profit expectations.

Countries that are unable to save enough and have saving deficit, aim to increase their production volumes by hosting foreign direct investments, thus providing high earnings, employment potential and technology transfers. To this end, foreign direct investment is being encouraged for host countries. Foreign direct investment is a bigger priority for developing countries. In these countries, the inadequacy of capital accumulation and low level of savings can lead to inadequate investments. This situation causes the production level of the countries and the national income decrease accordingly. Inadequate production causes the level of employment fall below potential and income per capita stabilize at rather low levels. Thus, developing countries are constantly seeking to break this vicious circle of poverty, and one of the potential ways to do that is through foreign direct investments' inflow. In other words, developing economies often hope to find solutions to their chronic economic problems via FDI inflows.

The influence of globalization and neoliberal policies has increased the interdependence of all countries. This necessitates greater cooperation with foreign traders and investors, but also requires the presence of foreign trade in these countries. For this reason, they should not be independent of financial, political and socioeconomic developments in the world beyond their national boundaries. Any socioeconomic development experienced by trade partners in the course of their cross-border cooperation affects these countries rather spontaneously. Similarly, political risks posed by trading partners can affect trade and investment volumes on both sides of cooperation.

The tendency of developing countries' shares' increase in the global FDI volumes which is mostly due to political and economic vulnerability of the early 2000 s is also reflected the investors' most worried factors. The World Investment and Political Risk (WIPR) Report of the Multilateral Investment Guarantee Agency (MIGA) as of 2013 shows that political risks are second only to macroeconomic stability with little difference (World Bank, 2014).

According to the UNCTAD database, by the end of 2016 the total FDI inflows in the world reached the level of approximately 1,8 trln USD, with 1 trln falling on developed countries and the rest of 600 bln - on developing countries. FDIs which demonstrated several falls before and after the global crisis, increased in 2015 and then in 2016. During the Arab Spring of 2010 which spread all over the Middle East and North Africa (MENA) countries and was triggered by socioeconomic reasons as well as political corruption, the effects of political risks on FDI volumes were felt quite strongly. Events related to political and global concerns such as the 9/11 attacks in the USA, the London subway attack, the Spanish attack, tensions in the Middle East, the Arab Spring, the Syrian crisis and the immigrant problems show how political risks can affect FDI volume and how difficult it can be to foresee those risks due to the impossibility to predict such events. In addition, security threats and terrorist attacks in developed countries confirm the assumption that political risks are not be limited only to developing countries with their governmental instability. This situation makes FDI investors' decision-making an even more difficult task.

This study attempts to theoretically examine the effects from political risks on foreign direct investment decisions. First, the concept of risk will be defined, then the concept and types of political risk will be explained. Statistical data on both variables will be presented, 


\section{FOREIGN DIRECT INVESTMENTS UNDER IMPACT}

specifying the foreign direct investments and the key determinants behind them. After clarifying the theoretical effect of political risks on FDI decisions, the study will be completed by giving a brief summary in the conclusion part.

\section{Theoretical background}

Macroeconomic variables, political risks and institutional quality variables are often emphasized in literature as being the main determinants of foreign direct investments. Very different results though are obtained in different studies concerning the relation between political risks and FDIs. This is because different forms and manifestations of political risk are discussed, differences in the development level of certain countries also have their influence, and different time periods are as well as different countries, country groups and regions.

Stoever (2002) developed a model on the data of South Korea, covering the period from 1962 to 2000. This author found that less political risk stimulates increases in foreign direct investments.

Roll and Talbott (2001) analyzed the GNI per capita across 162 different countries, the data covering 1995 to 1999 years. They found that variation in GNI per capita depended on the freedom of press, political rights, property rights, government expenditures and civil liberties. According to results these variables influenced the GNI per capita positively. But trade barriers, poor monetary policy, excessive regulation and black market activity had negative effect on GNI. They also found that democracy affects GNI positively.

Tallman (1988) examined the effects of economic and political conditions on FDI in developed countries, 1974 to 1980 . According to their results, FDI decisions significantly depend upon political and economic conditions.

Wheeler and Moody (1992) found that corruption rate in a host country doesn't have any significant effect on foreign direct investments, however, we need to note that their study was carried out on the micro level and concerned USA only.

Erramilli and Rao (1993) examined the relationship between political risk and FDI on the data of 114 firms carrying out a survey for analyzing their decisions to enter foreign markets. They concluded that the sovereign risk tends to hinder the flow of foreign direct investment and for the same reason multinational companies hesitate to make new investment decisions in relation to countries that demonstrate higher political risks.

Singh and Jun (1995) performed an empirical analysis on the data between 1970 and 1993 and on 31 countries. They studied the macroeconomic and sociopolitical variables affecting the geographical distribution of foreign direct investments. Political risk and business conditions were found to be quite influential determinants of FDI.

Grosse and Trevino (1996) analyzed the relationship between political risks and FDI in the case of the USA for the period from 1980 to 1991. They found a statically significant effect of political risk on FDI in the USA.

Wei (2000) concluded that there is a significant relationship between corruption rate and FDI. According to their results, corruption decreases FDI volumes and also influences import capital in terms of both volume and structure.

Noorbakhsh et al. (2001) found that democracy and political risk had no significant effect on FDI for 36 different developing countries from Africa, Asia and Latin America. They analyzed the data covering the years from 1980 to 1994. 
Kolstad and Tondel (2002) found that corruption had no significant effect on FDI. But political rights, civil freedom, democratic accountability, religious and ethnic tensions and other forms of internal conflict had important effects on FDI for 61 different developing countries, 1989 to 2000 .

Trevino and Mixon (2004) concluded that institutional reform can be a significant variable for FDI in the case of Latin America (Argentina, Brazil, Chile, Colombia, Mexico, Peru and Venezuela). Their dataset covered the years between 1988 and 1999.

Grosse and Trevino (2005) conducted a study on the relationship between institutional variables and FDI for Central and Eastern European countries. They found that corruption, political risk and foreign direct investment flows were negatively related.

Daude and Stein (2007) analyzed the nexus between institutional quality on foreign direct investment for 34 source country and 152 host countries. They used the data for 1982 and 2002 years and found that institutional quality affects FDI flows positively.

Busse and Hefeker (2007) investigated the relationship between political risk and FDI flows in 83 developing countries. Their analysis captured the data in the period from 1984 to 2003. According to their findings, government stability, internal and external conflicts, corruption and ethnic tensions, law and order, democratic accountability of the government and the quality of bureaucracy variables are all statistically significant for FDI.

Krifa-Schneider and Matei (2010) performed the analysis of the relationship between political risk, business environment and FDI for 33 different developing and transition countries. They found that lower political risk level induced higher rates of FDI and also that business climate is a significant determinant for FDI inflows.

Hayakama et al. (2011) conducted the analysis for 93 countries (1985 to 2007) in order to determine the effects of political and financial risks on FDI inflows. They found that political risk affects FDI inflows and also that socioeconomic conditions, investment conditions and the presence of external conflict are quite affecting variables for FDI.

Baek and Qian (2011) carried out a panel analysis for 22 industrialized and 94 developing countries between the years 1984 and 2008. They aimed to find whether political risk affects FDI or not. According to their findings, political risk is statistically significant for FDI. And after the 9/11 attacks political risk got even higher importance for determining the FDI volumes in developed countries. They used 12 different political risk variable in their analysis.

Aguiar et al. (2012) investigated the effects of political risk on FDI inflows into 180 different countries. Their findings showed that higher political risk decreased FDI inflow into a host country.

Sedik and Seoudy (2012) analyzed the relationship between country risk and FDI for 20 MENA countries. Their data included the years 1999 and 2010. Their findings showed that lower political risk affects FDI positively but economic and financial risks have insignificant and positive effects on FDI.

Sissani and Belkacem (2014) investigated the relationship between FDI and political and financial risk during 1992-2012. According to their results for Algeria, FDI was negatively affected by political risk factors.

Benacek et al. (2014) investigated the relationship between political and economic risk on FDI for 35 host countries in Europe, their data covered the years between 1995 and 2008. And their findings indicated that these risks don't always affect FDI negatively. 


\section{FOREIGN DIRECT INVESTMENTS UNDER IMPACT}

Al-Khouri and Khalik (2013) analyzed political, financial and economic risk effects on FDI in 16 MENA countries. Their data covered the time period between 1984 and 2011. And these authors found a significant relationship between FDI, market size, political risk and foreign direct investment. They also highlighted that corruption level, external conflict (tension) and FDI were closely correlated in the context of 12 political risk variables.

Erkekoğlu and Kilicarslan (2016) analyzed the impact of political risk on FDI for 91 different countries using the panel data that covered the period of 2002-2012. According to their results, higher political stability, absence of violence and management effectiveness reduce FDI. However, higher value of exportation of goods and services, population, GDP growth and regulatory quality increases FDI volumes, and this result is applicable to all 91 countries.

Kirikkaleli (2016) explored the relationship between financial, economic and political risk variables for seven Balkan countries. According to his results, financial and economic stability had positive relationship, but financial stability influenced the political stability negatively in the long run.

\section{Theoretical relationship between political and economic risk and FDI}

All countries, especially developing ones, need foreign direct investment / investors' interest for achieving their economic growth goals. But the most important elements that attract foreign investment into a country are positive development of macroeconomic indicators and the reduction of political risks. For this reason, countries that aim to be hosts for foreign direct investment are supposed to maintain stability in both macroeconomic situation and political life. After the conceptual analysis of political risks and foreign direct investments in the following sections, the prevailing and recent trends of FDI development will be presented statistically.

\section{Definition of Political Risk}

It would be appropriate to start with the definition of political risk prior to FDI analysis. Political risk refers to the damage or influence of businesses as a result of attitudes and behaviors demonstrated by politicians along with the costs of the related political (McKellar, 2010:3). Political risk is of non-commercial nature but it is still strongly correlated with market conditions (Kansal, 2015). Political risk usually covers various internal and external conflicts, terrorist acts, riots, wars, questionable government regulations, too heavy tax burden, corruption, protectionism measures, trade unions restrictions, tariffs, price controls, currency convertibility, restrictions imposed on repatriation of profits, expropriation of assets, potential risk of nationalization etc.

The most common form of political risk is imposing special requirements or taxes on foreign trader and investors with the aim to make foreign companies' profit transfers difficult, thus providing an additional incentive to local firms. Besides, inconvertibility of a host country's currencies can be evaluated within the scope of political risk for FDI. However, the most important political risk factors - the ongoing war or a war threat - can have much more devastating effects on foreign investment. In addition, excessive bureaucracy and high corruption rates as a political risk factor also lower the profitability of companies by imposing additional costs while making the work environment more hazardous (Dzidrov and Dzidrov, 2010:553). 


\section{Types of Political Risk}

It is obvious that political risk, similar to other types of risk, has its negative influence on every economy. Political risk can arise from local elections, internal and external riots, rebellions, economic stagnation or war threats. Increased political risk can deter foreign investors due to potential confiscation of their assets, sudden increase in taxes and/or tariffs, more incentives provided to local investors, high costs of local raw materials and/or intermediaries' services, or difficulties with money convertibility etc. The net macroeconomic effects from the decline in foreign investors' activities due to increased political risk may lead to delays or halt of production, loss of property, increase of import costs, reduction of incomes, managerial obstacles, higher operating costs or transfer of profits into another country. On the macrolevel, mismanagement of the economy leads to increased costs due to increases in inflation and interest rates, thus making long-term investment decisions more difficult (Bhalla, 1983; McGowan and Moeller, 2009; Kruja and Dragusha, 2014).

Different types of tensions between countries have different consequences for international investment and trade decisions. Strategic and economic tensions between national governments arise for a variety of reasons. This can be a long-lasting unresolved border conflict that is gradually becoming an armed one (as in the Arab-Israeli case). Fundamental differences in national ideologies can also cause countries to see other countries as being inadequate (for example, the liberal capitalist Western Bloc vs. the authoritarian communist Eastern Bloc during the Cold War, or the conflict between Iran and the West today). When there is distrust on the cultural and historical levels, it may also cause tensions between countries. Tensions between countries can disrupt supply chains or cause other external economic damages. Governments' campaigns for providing preferences and consuming more of domestic goods as well as tariffs on foreign trade can create serious barriers to market entry (as it happened during the US-Japanese trade wars) (McKellar, 2010: 12-14).

Hamada et al. (2004) divided political risk into three broad categories:

- Expropriation risk is the risk of damage an investor may incur due to the loss of ownership or control over the investment after certain actions taken by a host government. Moreover, in the case of debt, project enterprise can't meet the lender's demands. Today, expropriation or "lack of wealth" can emerge in different ways: it can be either an expropriation of an investment, or a complete, physical takeover.

- Transfer risk is the difficulty with converting local currency (capital, interest, profit, royalties and other charges) into foreign ones. Sometimes local governments can make it difficult for foreign investors to transfer capital. This situation harms the interests of foreign investors and thus discourages them from investing into this particular country.

- Political violence risk is a loss and harm that will result from the destruction of physical assets as a result of political directives or as caused by government-related events such as revolution, terrorism, sabotage, military uprising, revolt, insurrection, coup, war or civil disorder (Kruja and Dragusha, 2014).

\section{Theoretical Relationship between Political and Economic Risks and FDI}

Most of political risks arise from government interventions into business operations, local or international. 


\section{FOREIGN DIRECT INVESTMENTS UNDER IMPACT}

The whole variety of political risks can be largely divided into macropolitical and micropolitical risks. Macropolitical risks concerns expropriation most often, they can be also generally presented as the risks affecting all foreign firms operating in the same country. These include: tax law amendments, price control, strict environmental regulations, restrictions on capital transfers, and restrictions on foreign ownership. Micropolitical risks usually affect certain sectors only and they may vary by industry, project or firm (Bayraktutan and Tari, 2016:93).

Nowadays, policies on foreign investments are becoming increasingly complex and uncertain. Besides, it is becoming increasingly difficult for governments to develop these policies, not contradicting globalization trends at the same time. The factor of hypothetical government intervention hinders the predictability of international investments. In order to reduce uncertainty and establish a regular investment relationship in today's business world, there is a need for reliable and comprehensive investment regimes, open to cooperation and supporting the sustainable development (UNCTAD Investment Report, 2017).

Multinational corporations need to find a balance between developing countries with their usually low political risks and low costs on the one side and developed countries with their high political stability but also higher costs of hosting, on the other. In many cases multinational businesses already had a chance to prove that developing countries have a more stable political structure due to decreased political risks (Baek and Qian, 2011:14).

The countries with higher democratic accountability tend to absorb more FDI flows. Democratic accountability reduces economic turmoil and provides a more robust business environment for foreign investors (Büsse and Hefeker, 2007).

Political risk go way beyond the commercial risks, also, they may be limited to the host country only or may belong to the international environment. Unlike with some other determinants, political risks, in most cases, can't be precisely predicted, thus they can quickly lead to a deterioration of the investment climate, weakening of the investors' rights, problems with their ownership of assets etc. - all due to sudden changes in the political environment of host countries (Bayraktutan and Tari, 2016:92).

Effects from political risks on investment decisions can be narrowed down, actually. One of the political risk indicators is, for example, corruption, it always has a major impact on FDI decisions. Same applies to bureaucracy, transparency of government policies and actions, the risk of expropriation and nationalization of the assets, public intervention in the course of doing business etc. (Banacek et al., 2010).

According to the survey conducted by the World Bank on the most important constraints imposed on foreign investment decisions (see the results of this research in Table 1 below), the major of them are as follows: the lack of talented employees, financial difficulties, macroeconomic instability, while political risks and corruption also got quite many votes, inter alia. 
Table 1 - Major Constraints to FDI (\%)

(Source: WIPR-2013:7)

\begin{tabular}{|l|c|c|c|c|}
\hline & 2010 & 2011 & 2012 & 2013 \\
\hline Number of respondents & 94 & 316 & 438 & 459 \\
\hline Limited size of the local market & 9 & 7 & 7 & 5 \\
\hline Lack of investment opportunities & 7 & - & - & - \\
\hline Poorly developed infrastructure & 9 & 11 & 8 & 7 \\
\hline Lack of qualified staff & 10 & 17 & 18 & 18 \\
\hline Lack of assets to carry out the investment & 5 & 11 & 13 & 13 \\
\hline Political risks & 21 & 18 & 22 & 19 \\
\hline Macroeconomic instability & 16 & 15 & 20 & 21 \\
\hline $\begin{array}{l}\text { Lack of information on the country's business } \\
\text { environment }\end{array}$ & 2 & - & - & - \\
\hline Weak government institutions/red tape/corruption & 19 & 13 & 8 & 10 \\
\hline $\begin{array}{l}\text { Increased government regulation in the aftermath of } \\
\text { the global financial crisis }\end{array}$ & - & 5 & 3 & 4 \\
\hline
\end{tabular}

According to the results of the same World Bank survey, the most important political risks for the investors entering the markets of developing countries have been identified. According to the results in Table 2, the most important political risks concern: regulatory changes, breach of contract, transfer and convertibility restrictions, civil disturbance, nonhonoring of financial obligations, expropriation, terrorism and war.

Table 2 - Types of Political Risks that Concern Investors in Developing Countries the Most (\%)

(Source: WIPR-2013)

\begin{tabular}{|l|c|c|}
\hline & $\begin{array}{c}\text { For the next 3 } \\
\text { years }\end{array}$ & $\begin{array}{c}\text { For the next 12 } \\
\text { months }\end{array}$ \\
\hline Adverse regulatory changes & 58 & 56 \\
\hline Breach of contract & 45 & 45 \\
\hline Transfer and convertibility restrictions & 43 & 37 \\
\hline Civil disturbance & 33 & 30 \\
\hline Non-honoring financial obligations & 31 & 27 \\
\hline Expropriation & 24 & 19 \\
\hline Terrorism & 13 & 11 \\
\hline War & 7 & 6 \\
\hline
\end{tabular}

According to the MIGA's survey, the most influential factors often violating of the investors' contracts are listed as follows: crisis (29\%), political regime change in the destination country (14\%), corruption/red tape (11\%), sovereign state default (10\%), political instability/war (9\%), non-discriminatory regulatory or policy changes (e.g., increase of tax rates, subsidy cuts, deprival of licenses) (6\%), frequent and/or sudden changes in input prices (5\%) (World Bank, 2014). 


\section{FOREIGN DIRECT INVESTMENTS UNDER IMPACT}

The ongoing debate so far has shown how direct foreign investments are influenced by the rise in political interest in addition to the instability of macroeconomic variables. It is emphasized that developing countries especially need direct foreign investments for their further economic growth and creation of new employment areas. In order for all economies to attract more foreign direct investment, especially developing ones, it is necessary to reduce both macroeconomic and political risks. For this reason, governments of developing countries have to take more precautions about their political risks in order to obtain more FDI.

\section{Conclusion}

Trade and investment decisions are strongly influenced by risk factors. International investment decisions, however, require taking into account quite different risks as opposed to domestic investments. Unlike portfolio investments and short-term capital movements, foreign direct investments have some difficulties due to additional reasons such as sunk costs, irreversibility of investment and difficulty in transferring profit and capital to a country. Similarly, political risks have a strongly negative impact on FDI decisions.

Over the last decade, FDIs have increased considerably on the global scale and has shown significant changes in the recent years. In developing countries, factor prices can become attractive centers for foreign investment due to their relatively lower costs, ease of competitiveness and wider market size. However, developing countries have a lower share of FDIs due to the high level of political risk variables.

In order to increase the share of FDI inflows with significant positive externalities and spillover effects for developing countries, it is necessary to reduce political risk factors as well as to improve macroeconomic variables. As a matter of fact, in recent years, countries with a large share of FDI inflows on the global scale, more or less macroeconomically sound and with less political risks, have managed to attract more FDI.

\section{References:}

Aguiar, S., Aguiar-Conraria L., Gulamhussen M.A. \& Magalhaes P.C. (2012). Foreign Direct İnvestment And Home-Country Political Risk: The Case of Brazil, Latin American Research Review, 47(2). 144-165.

Al-Khouri, R., \& Abdul Khalik, U. (2013). Does Political Risk Affect the Flow of Foreign Direct Investment into the Middle East North African Region. Journal of Global Business and Technology, 9(2). 47-63.

Baek K. \& Qian X.(2011). An Analysis on Political Risks and the Flow of Foreign Direct Invesment in Developing and Industrialized Economies. Economics, Management and Financial Markets, 6(4). 60-91.

Bayraktutan, Y. \& Tarı Ö.M. (2016). Politik Riskler, İki Taraflı Yatırım Anlaşmaları ve Uyuşmazlıklar Bağlamında Doğrudan Yabancı Yatırımlar [Foreign Direct Investments at the Context of Political Risks, Bilateral Investment Agreements and Disputes], Uluslararast Ekonomik Araştırmalar Dergisi [International Journal of Economic Studies], 2(4). 87-104. (in Turkish). 
Benáček, V., Lenihan, H., Andreosso-O'Callaghan, B., Michalíkov, E. \& Kan, D. (2014). Political Risk, Institutions and Foreign Direct Investment: How Do They Relate in Various European Countries?, The World Economy, 37(5). 625-653.

Bhalla, B. 1983. How Corporations Should Weigh Up Country Risk. Euromoney, June. 66-72.

Busse, M., \& Hefeker, C. (2007). Political Risk, Institutions And Foreign Direct Investment. European Journal of Political Economy, 23(2). 397-415.

Daude, C. \& Stein, E. (2007). The Quality Of Institutıons And Fore1gn Direct Investment, Economics \& Politics, 19(3). 317-345.

Dzidrov M. \& Dzidrov M. (2010). Political and Economic Risk Analysis Case study of Macedonia. The Conference on Web-Based Business Management.http://file.scirp.org/pdf/18-1.8.14.pdf

Erkekoglu, H. \& Kilicarslan, Z. (2016). Do Political Risks Affect the Foreign Direct Investment Inflows To Host Countries? Journal of Business, Economics and Finance, 5(2), 218-232.

Erramilli, M. \& Krishna C. P. Rao. (1993). Service Firms' International Entry-Mode Choice: A Modified Transaction-Cost Analysis Approach. Journal of Marketing, 57(3). 19-38.

Grosse, R. \& Trevino, L.J. (1996). Foreign Direct Investment in the United States: An Analysis by Country of Origin. Journal of International Business Studies, 27(1). 139-155.

Hayakawa, K., Kimura, F., \& Lee, H. (2011). How does country risk matter for FDI. Institute of Development Economies Paper, (281).

Hamada, J., Haugerudbraaten, H., Hickman, A., \& Khaykin, I. (2004). Pricing Political Risk within an Economic Capital Framework, In: Country and Political Risk: Practical Insights for Global Finance, ed. Sam Wilkin, Risk Books, England.

Kansal, V. (2015). Political Risk: Conceptualization, Definition, Categorization and Methodologies. The Journal of Politik Risk, 3(4).

Kirikkaleli, D. (2016). Interlinkage Between Economic, Financial, and Political Risks in the Balkan Countries: Evidence from a Panel Cointegration. Eastern European Economics, 54:3. 208-227.

Kolstad, I. \& L. Tondel. (2002). Social Development and Foreign Direct Investment in Services. CMI Report 2002: 11, Chr Michelsen Institute, Bergen.

Krifa-Schneider, H. \& Matei, I. (2010). Business Climate, Political Risk and FDI in Developing Countries: Evidence from Panel Data, International Journal of Economics and Finance, 2(5). 54-65.

Kruja, A. \& Dragusha, B. (2014). The Impact of Political Risk on Foreign Direct Investment. Iliria International Review, 2014/2. 73-92.

McGowan, Jr. C.B. \& Moeller, S.E. (2009). A Model for Making Foreign Direct Investment Decisions Using Real Variables for Political and Economic Risk Analysis, Managing Global Transitions International Research Journal, 7(1). 27-44.

McKellar, R. (2010). A Short Guide to Political Risk, Gower Publishing Limited, England.

Noorbakhsh, F., Paloni, A. \& Youssef, A. (2001). Human Capital and FDI Inflows to Developing Countries: New Empirical Evidence. World Development, 29. 1593-1610.

Roll, R. \& Talbott, J. (2001). Why Many Developing Countries Just Aren't, The Anderson School at UCLA, Finance Working Paper No. 19-01. Available at SSRN: https://ssrn.com/abstract=292140 or http://dx.doi.org/10.2139/ssrn.292140.

Sedik, W.M. \& Seoudy, H. (2012). The Impact of Country Risk and New Institutional Economics on Foreign Direct Investment A Panel Data Analysis for Middle East and North Africa Region 


\section{FOREIGN DIRECT INVESTMENTS UNDER IMPACT}

(1999-2010), The 16th Meeting of the International Society for New Institutional Economics, University of Southern California on June, 2012.

Sissan1, M. \& Belkacem, Z. (2014). The Effect of Political Risk on Foreign Direct Investment: The Case of Algeria, Hyperion Economic Journal, 3(2). 29-35.

Singh, H. \& Jun, K.W. (1995). Some New Evidence on Determinants of Foreign Direct Investment in Developing Countries. World Bank Policy Research Working Paper, No. 1531, Available from URL: http://ssrn.com/abstract=623885 .

Stoever, W. (2002). Attempting to Resolve The Attraction-Aversion Dilemma: A study of FDI Policy in the Republic of Korea. Transnational Corporations, 11 (1). 49-76.

Tallman, S.B. (1988). Home Country Political Risk and Foreign Direct Investment in The United States. Journal of International Business Studies, 19 (2). 219-233.

Trevino, L.J. \& Mixon, F.G. (2004). Strategic Factors Affecting Foreign Direct Investment Decisions by Multinational Enterprises in Latin America, Journal of World Business, 39(3), 233-243.

UNCTAD (2017). World Investment Report 2017: Investment and The Digital Economy, UN Publication, Geneva.

Wei, S. J. (2000). How Taxing Is Corruption On International Investors? The Review of Economics and Statistics, 82(1), 1-12.

Wheeler, D. \& Moody, A. (1992). International Investment Location Decisions: The Case of US Firms. Journal of International Economics, 33. 57-76.

World Bank (2014). World Investment and Political Risk (WIPR)-2013: World Investment Trends and Corporate Perspectives, The Political Risk Insurance Industry, Breach of Contract, MIGA, World Bank Group. Washington, D.C.

Paper submitted

Paper accepted for publishing

Paper published online
16 September 2018

01 December 2018

31 January 2019 